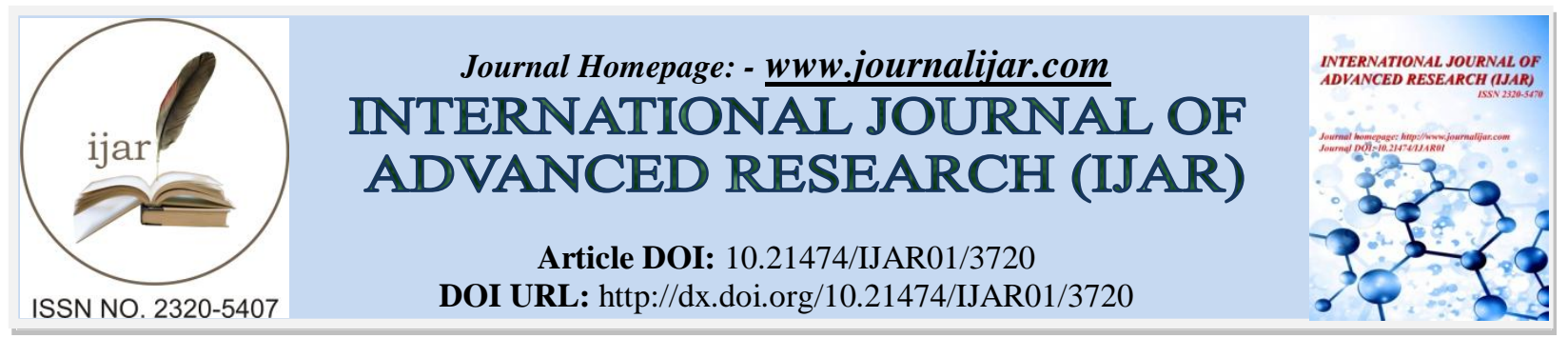

RESEARCH ARTICLE

\title{
EFFECT OF TEMPERATURE AND IRRADIANCE ON THE ELECTRICAL PERFORMANCE OF A PV MODULE.
}

\author{
Usha Mandadapu ${ }^{1}$, S. Victor Vedanayakam ${ }^{1}$ and K. Thyagarajan ${ }^{2}$. \\ 1. Department of Physics, Madanapalle Institute of Technology and Science, Madanapalle. A.P. India. \\ 2. Department of Physics, JNTUCEP. Pulivendula, A.P. India.
}

\section{Manuscript Info}

[.........................

Manuscript History

Received: 15 January 2017

Final Accepted: 06 February 2017

Published: March 2017

Key words:-

Solar cells, Temperature, Irradiance,

Efficiency, MATLAB, Simulation.

\section{Abstract}

Solar cells are the devices, which convert the solar radiation into the electrical energy without effecting the environment. To predict the real behavior of solar cells like changes in maximum power, short circuit current and open circuit voltage by changing the temperature and irradiance can be studied by using the MATLAB (simulation model). In this paper, a single diode MATLAB model is used to study the changes in solar PV module by varying temperature $(100 \mathrm{C}, 200 \mathrm{C}, 300 \mathrm{C})$ and by varying the irradiance $(400 \mathrm{~W} / \mathrm{m} 2,600 \mathrm{~W} / \mathrm{m} 2$, $800 \mathrm{~W} / \mathrm{m} 2)$. To study the changes in electrical parameters of a solar PV modules KD330GX-LFB and KD325GX-LFB experimental data sheet are taken and the results are discussed in the conclusion.

Copy Right, IJAR, 2017,. All rights reserved.

\section{Introduction:-}

The continuous use of fossil fuels for industrial purpose leads to huge damage to eco system and living conditions. To sustain our earth, the mankind has to decrease the green house gases like $\mathrm{CO}_{2}$, Methane.., by choosing alternatives to fossil fuels. In order to conserve natural living spaces and not to harm the next generation utilization of renewable energy should increase. Among all the renewable energy sources, solar energy is having the large potential and small amount of it is utilizing for various purposes. Photovoltaic Effect converts solar energy to the electrical energy. Widely used applications of PV system are water heaters, street lights, electric vehicles, military and space applications $(1,2)$. Solar panels and modules are works on the principle of Photo voltaic effect, and generates the electric power. These PV modules and panels are largely effected by different weather conditions. In this paper, mainly modeling parameters are explained. By changing the temperature of a simulink PV module, the changes in output parameters are observed. The simulated results are compared with the KD330GX-LFB, KD325GX-LFB experimental results.

State of Art: Swapnil Dubey.et.al, investigated the temperature Effect on the solar panel. they concluded that numerical parameters or equations are material dependent and also system dependent (3). Ike and C.U. investigated the effect of ambient temperature on performance .They observed the behavior of solar PV system under dry and rainy season in the year 2013. Conclusions came out as, the installation conditions shows the effect on the performance of PV panel(4). Khaled Matter, Hala.J.E-Khozondar.et.al. studied the shading effects on the maximum power point and remarkable reduction in efficiency of the soar PV system. Conclusions are there is a reduction in the maximum power point, by increasing temperature. To study the shading effects on the performance, they used the KC200GT panel(5).

Corresponding Author:- Usha Mandadapu.

Address:- Department of Physics, Madanapalle Institute of Technology and Science, Madanapalle. A.P. India. 
Tarak Salmi , Mounir Bouzguend, Adel Gastli, Ahmed Masmoudi developed solar PV module using basic semiconductor equations and they studied the performance of solar PV module under various atmospheric conditions(6). Jay Patel and Gaurang Sharma studied the characteristics of a module, they observed the solar cell performance under various temperature and irradiance conditions(7).

Characteristic I-V equation:- The I-V equation of a solar cell, which represents the output of a solar cell is described by few researchers from past four decades(8). The solar cells is generally represented by the single diode due to its simplicity in computational time. The Single diode solar cell can be modeled using the electrical components current source, parallel resistor, series resistor.

The single diode photovoltaic I-V equation (8):

$$
\begin{aligned}
& I=I_{p h}-I_{0}\left\{\exp \left(\frac{q\left(V+I R_{s}\right)}{A \cdot K \cdot T_{c}}\right)\right\} \\
& I_{p h}=G\left[I_{s c}+K_{1}\left(T_{c}+T_{r e f}\right)\right]
\end{aligned}
$$

Where

$$
\begin{aligned}
& \text { I } \mathrm{ph}=\text { Photo current } \\
& \text { Io=Saturation Current } \\
& \mathrm{Rs}=\text { Series resistance } \\
& \mathrm{A}=\mathrm{Ideality} \text { factor } \\
& \mathrm{K}=1.38 \times 10^{-23} \mathrm{~W} / \mathrm{m}^{2} . \mathrm{K} \text { (or) } 8.617 \times 10^{-5} \mathrm{eV} / \mathrm{K} \text {. } \\
& \text { I sc=Short circuit current. }
\end{aligned}
$$

Photo current $\left(\mathrm{I}_{\mathrm{ph}}\right)$ : The photo current is the electricity generated by the solar radiation and $\mathrm{I}_{\mathrm{ph}}$, explicitly depends upon cell temperature(T). Habbati. Bellia.et.al. Presented the detailed $I_{p h}$ equation as (9).

$$
\begin{aligned}
& I_{p h}=\frac{G}{G_{r e f}}\left[I_{p h}+\mu_{s c} \cdot \Delta T\right] . \\
& \Delta T=T_{c}-T_{c, r e f}
\end{aligned}
$$

Reverse Saturation Current: In solar cell, the reverse saturation current is produced due to the diffusion of charges from $\mathrm{n}$-side to $\mathrm{p}$-side and $\mathrm{p}$-side to $\mathrm{n}$-side. The equation for Io is given from the literature as

$$
I_{0}=D T_{C} 3 \exp \left(\frac{-q \epsilon_{g}}{A . K}\right)
$$

\section{$\mathrm{Tc}=$ Standard temperature.}

Ideality factor: The ideality factor gives us how closely the diode follows the ideal diode equation, the ideality factor is material dependent Some of the researchers like Bashahu and Nkunbabakura(12) used different methods to identify, ideality factor and suggested that it lies between 1.26 to 1.5 and ' $n$ ' is assumed to be independent of temperature and solar radiation(10).

Series Resistance(Rs):The movement of charges through the emitter and base, the contact resistances are the main reason for series resistance.

Series resistance is defined as: 


$$
R_{S}=-\left(\frac{d v}{d i}\right)-\frac{1}{X}
$$

Shunt Resistance: Manufacturing defects and poor solar cell design are the main reason for shunt resistance $\left(R_{\text {sho }}\right)$ , leads to power losses by flowing the light generated current in a alternative path. The deviation of current flow through the junction leads to decrease in the voltage of the cell.

The shunt resistance is defined as :

$$
\begin{aligned}
& R_{S}=R_{\text {sho }} \\
& R_{\text {sho }}=-\left(\frac{d v}{d I}\right)
\end{aligned}
$$

Simulink single diode model: To understand the effect of atmospheric variations on the performance of solar PV module, we need a computer based model. For this purpose, by using the semi conductor basic equations, a simulated single diode model is developed. By using that model, and changing the input parameters those are temperature and irradiance, we can observe the changes in the like P max, V mp, Imp, Voc, I sc from I-V, P-V graphs the and the following observations are tabulated.

Single Diode Model: Simulink model consists of few subsystems inter connected and the output is linked to the multi plot graphs(I-V and P-V graphs).The following figure represents the generalized model of PV module can be compared with the any practical device.

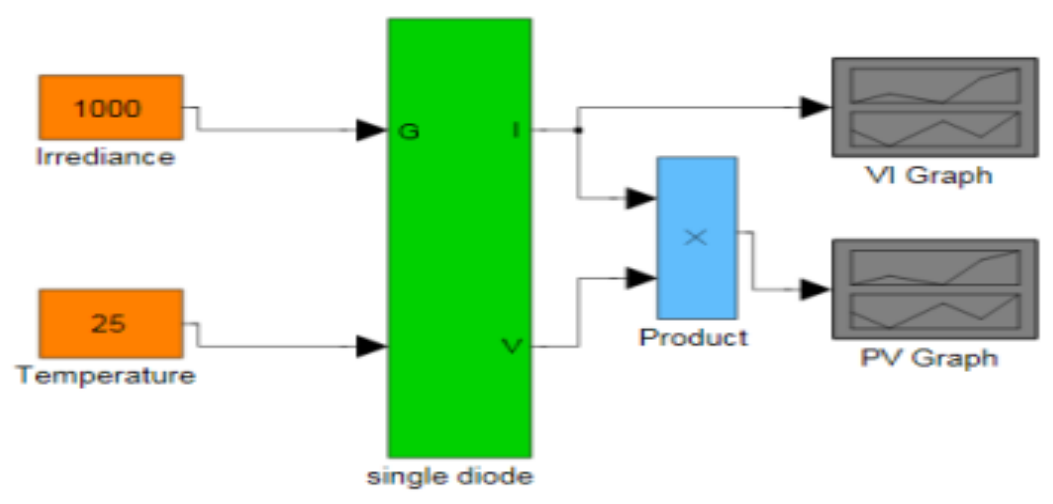

By varying the temperature: One of the input parameter Temperature change shows the major influence on the Performance of the module. The effect of temperature on KYOCERA KD330GX-LFB is observed by varying the temperature from $10^{\circ} \mathrm{C}$ to $30^{\circ} \mathrm{C}$, by an increment of $10^{\circ} \mathrm{c}$. The corresponding changes are tabulated and compared with the practical values. The resistances are identified for the simulink model by the Newton_ Rapshon numerical method. The resistances are Rs $=0.2500 \mathrm{ohm}$ and $\mathrm{Rp}=493.206 \mathrm{ohm}$ 
P-V Graph for KD330GX-LFB:-

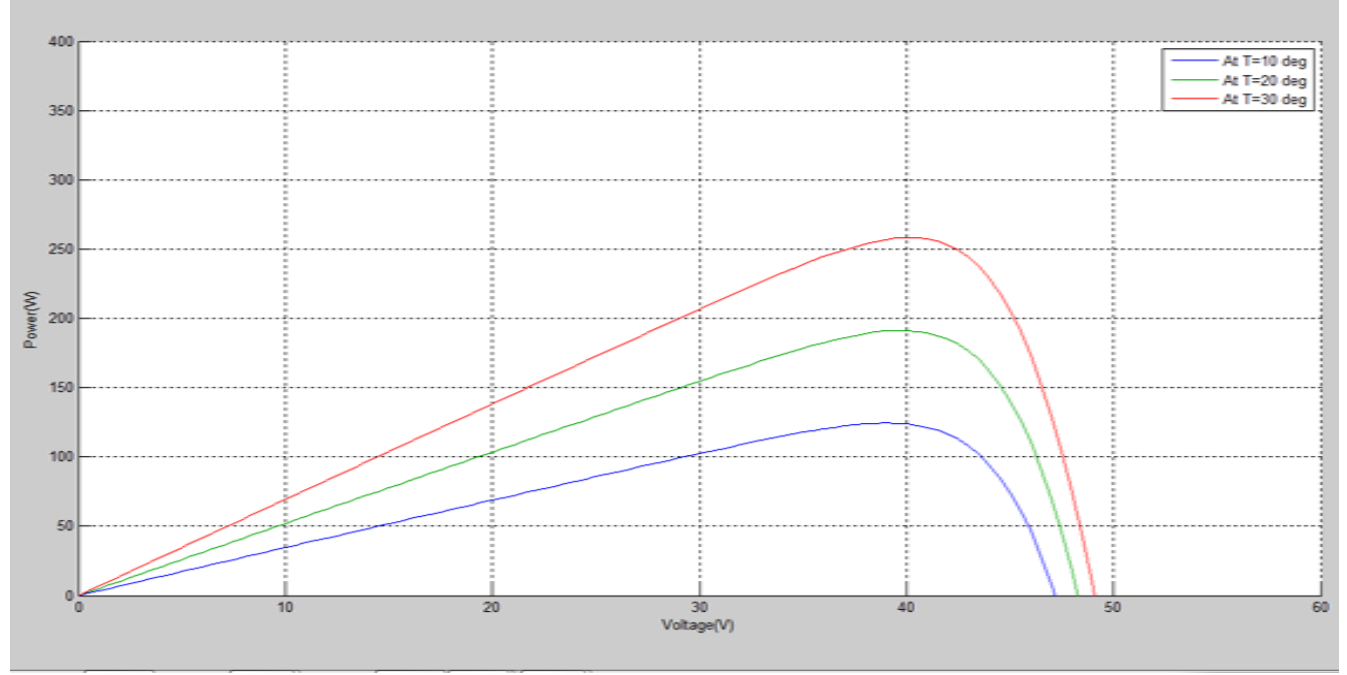

\section{I-V Graph KD330GX-LFB:}

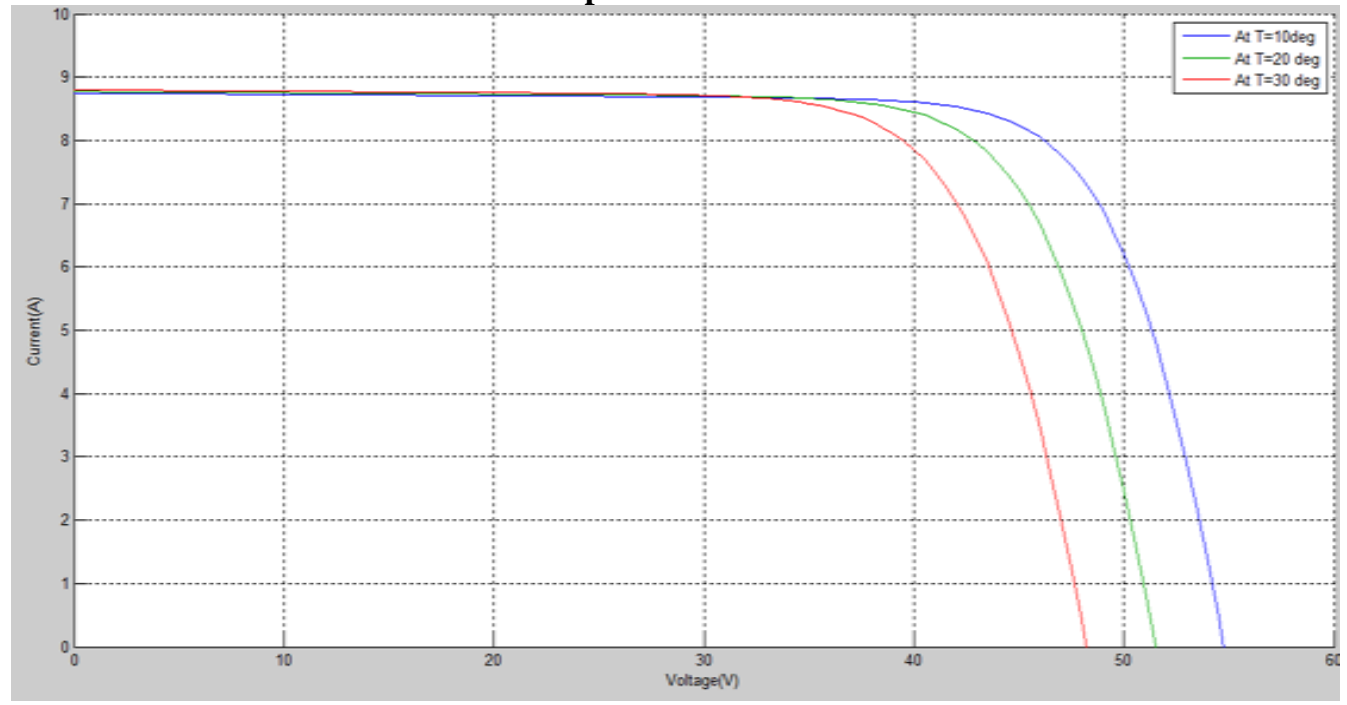

Table-1:-

Parameters of KD330GX-LFB

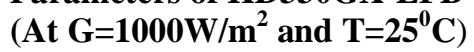

Pmax $=330(\mathrm{~W})$

$\mathrm{Vmp}=40.5(\mathrm{~V})$

$\operatorname{Imp}=8.15(\mathrm{~A})$

Voc $=49.9(\mathrm{~V})$

Isc $=$ 8.79(A)

\begin{tabular}{|c|c|c|}
\hline \multicolumn{3}{|c|}{ Simulink model Parameters at Different Temperatures } \\
\hline $\mathrm{T}=10^{0} \mathrm{C}$ & $\mathrm{T}=20^{\circ} \mathrm{C}$ & $\mathrm{T}=30^{0} \mathrm{C}$ \\
\hline 371 & 343.4 & 316.2 \\
\hline 45.5 & 42.5 & 39 \\
\hline 8.15 & 8.08 & 8.11 \\
\hline 54.8 & 51.6 & 48.2 \\
\hline 8.75 & 8.77 & 8.80 \\
\hline
\end{tabular}

Change of Efficiency with temperature:

Table-2:-

\begin{tabular}{|l|l|l|}
\hline Temperature $\left({ }^{0} \mathrm{C}\right)$ & Fill Factor $(\%)$ & Efficiency $(\%)$ \\
\hline $\mathbf{T}=10$ & $\mathbf{7 7 . 3 3}$ & 17.57 \\
\hline $\mathbf{T}=\mathbf{2 0}$ & $\mathbf{7 5 . 8 5}$ & $\mathbf{1 6 . 2 7}$ \\
\hline $\mathrm{T}=\mathbf{3 0}$ & $\mathbf{7 4 . 5 6}$ & 14.99 \\
\hline
\end{tabular}




\section{P-V Graph for KD325GX-LFB:}

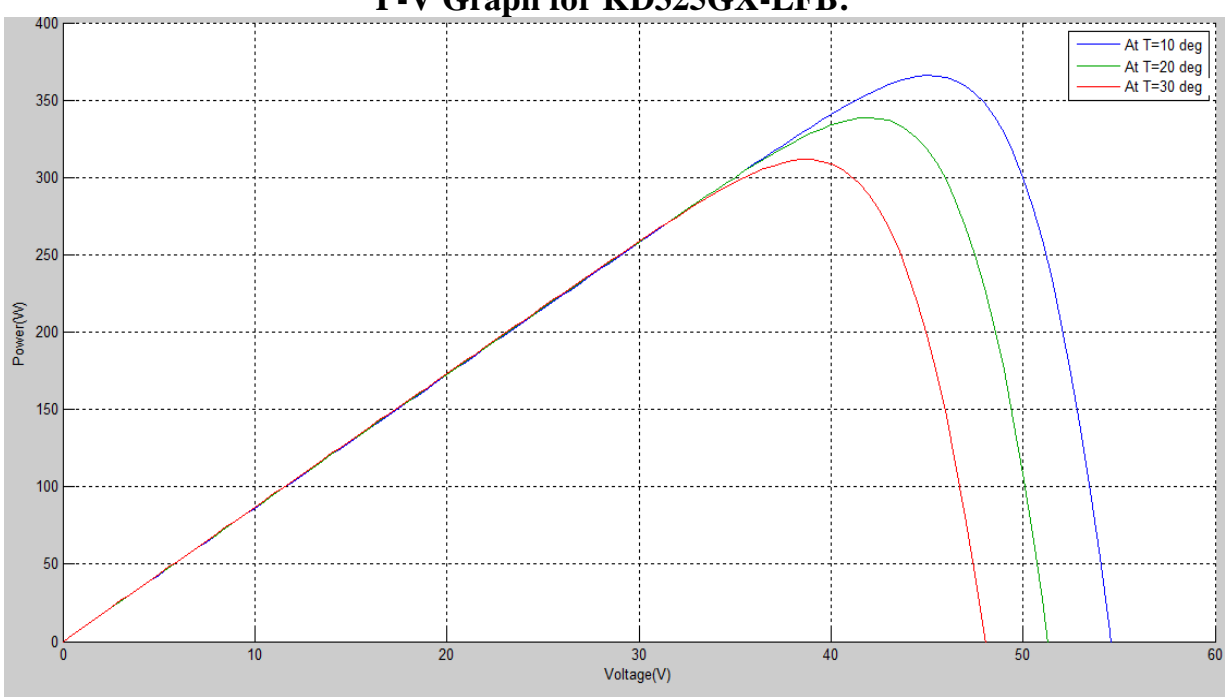

I-V Graph for KD 325GX-LFB:

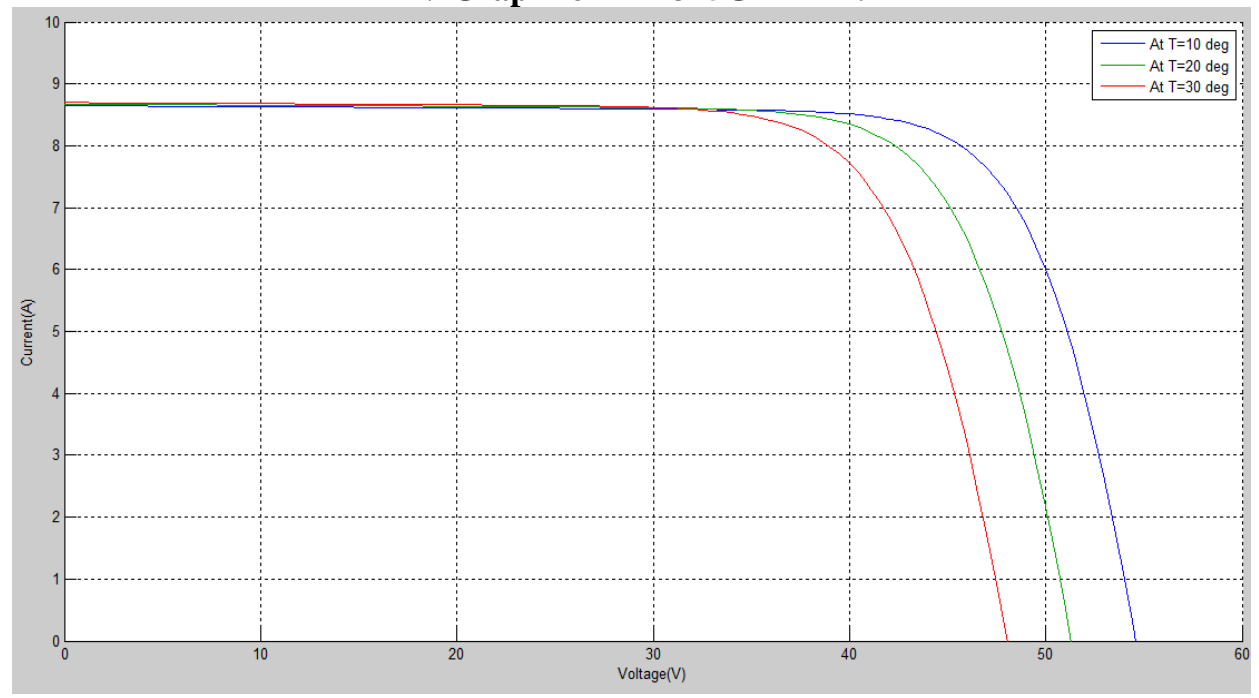

Table-3:-

\begin{tabular}{|c|c|c|c|}
\hline \multirow{2}{*}{$\begin{array}{l}\text { Parameters of } \\
\text { KD 325GX-LFB } \\
\text { At } \mathrm{G}=1000 \mathrm{~W} / \mathrm{m}^{2} \text { and } \\
\mathrm{T}=25^{0} \mathrm{C}\end{array}$} & \multicolumn{3}{|c|}{$\begin{array}{l}\text { Simulink model Parameters at } \\
\text { different Temperatures }\end{array}$} \\
\hline & $\mathrm{T}=10^{\circ} \mathrm{C}$ & $\mathrm{T}=20^{\circ} \mathrm{C}$ & $\mathrm{T}=\mathbf{3 0}^{0} \mathrm{C}$ \\
\hline $\operatorname{Pmax}=325(W)$ & 365.8 & 338.7 & 311.4 \\
\hline$V m p=40.3(V)$ & 45 & 42 & 39 \\
\hline $\operatorname{Imp}=8.07(\mathrm{~A})$ & 8.13 & 8.06 & 7.98 \\
\hline Voc $=49.7(V)$ & 54.6 & 51.3 & 48 \\
\hline $\mathrm{Isc}=8.69(\mathrm{~A})$ & 8.65 & 8.68 & 8.70 \\
\hline
\end{tabular}

Table-4:- Change of Efficiency with Temperature:

\begin{tabular}{|l|l|l|}
\hline $\begin{array}{l}\text { Temperature } \\
\left({ }^{0} \mathrm{C}\right)\end{array}$ & Fill Factor(\%) & $\begin{array}{l}\text { Efficiency } \\
(\%)\end{array}$ \\
\hline $\mathbf{T}=10$ & $\mathbf{7 7 . 4 6}$ & $\mathbf{1 7 . 3 3}$ \\
\hline $\mathbf{T}=\mathbf{2 0}$ & $\mathbf{7 5 . 0 2}$ & $\mathbf{1 5 . 0 5}$ \\
\hline $\mathbf{T}=30$ & $\mathbf{7 4 . 5 2}$ & $\mathbf{1 4 . 7 5}$ \\
\hline
\end{tabular}


The temperature change of KYOCERA KD330GX-LFB is observed for the temperatures $10^{\circ} \mathrm{C}, 20^{\circ} \mathrm{C}, 30^{\circ} \mathrm{C}$ and the changes in P max, V mp, Imp, Voc, I sc are taken from the I-V , P-V graphs and those values are tabulated. The resistances for KD330GX-LFB simulink model are identified using the Newton_Rapshon method those values are $\mathrm{Rp}=493.206 \mathrm{ohm}$ and $\mathrm{Rs}=0.2500$.

By Varying Irradiance: Solar module efficiency depends upon the input variable irradiance, as the irradiance is changed from $400 \mathrm{~W} / \mathrm{m}^{2}$ to $800 \mathrm{~W} / \mathrm{m}^{2}$ the output efficiency of a module changes. To study the changes in the performance of a solar PV module, KD330GX-LFB and KD325GX-LFB are studied and the results are tabulated.

\section{Simulink model of Single Diode model:}

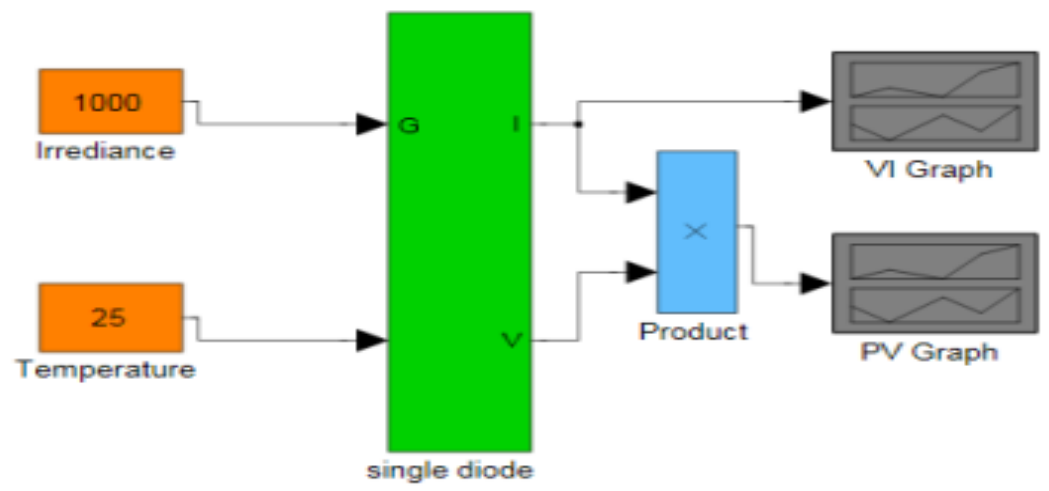

I-V Graph for KD330GX-LFB:-

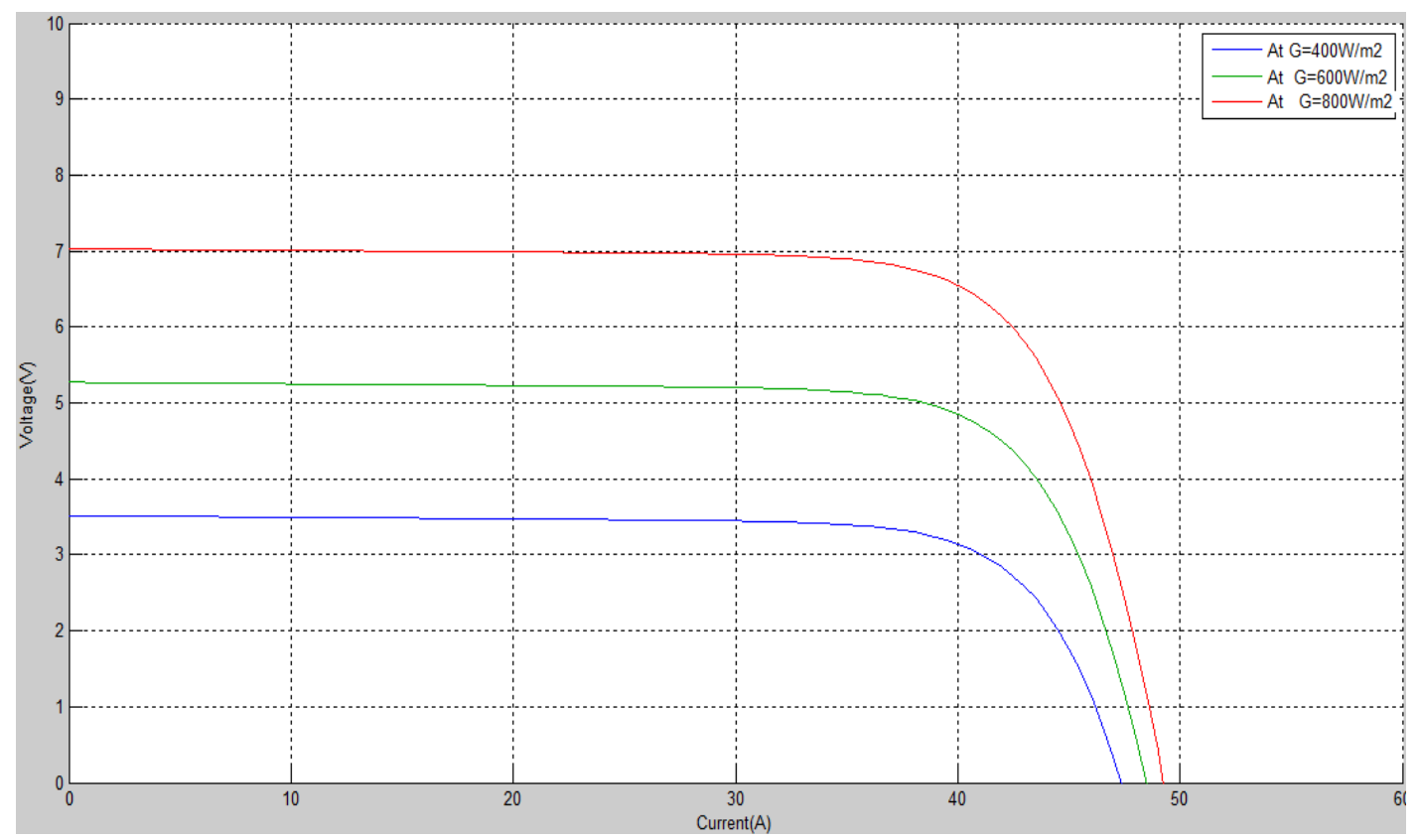

P-V Graph for KD330GX-LFB: 


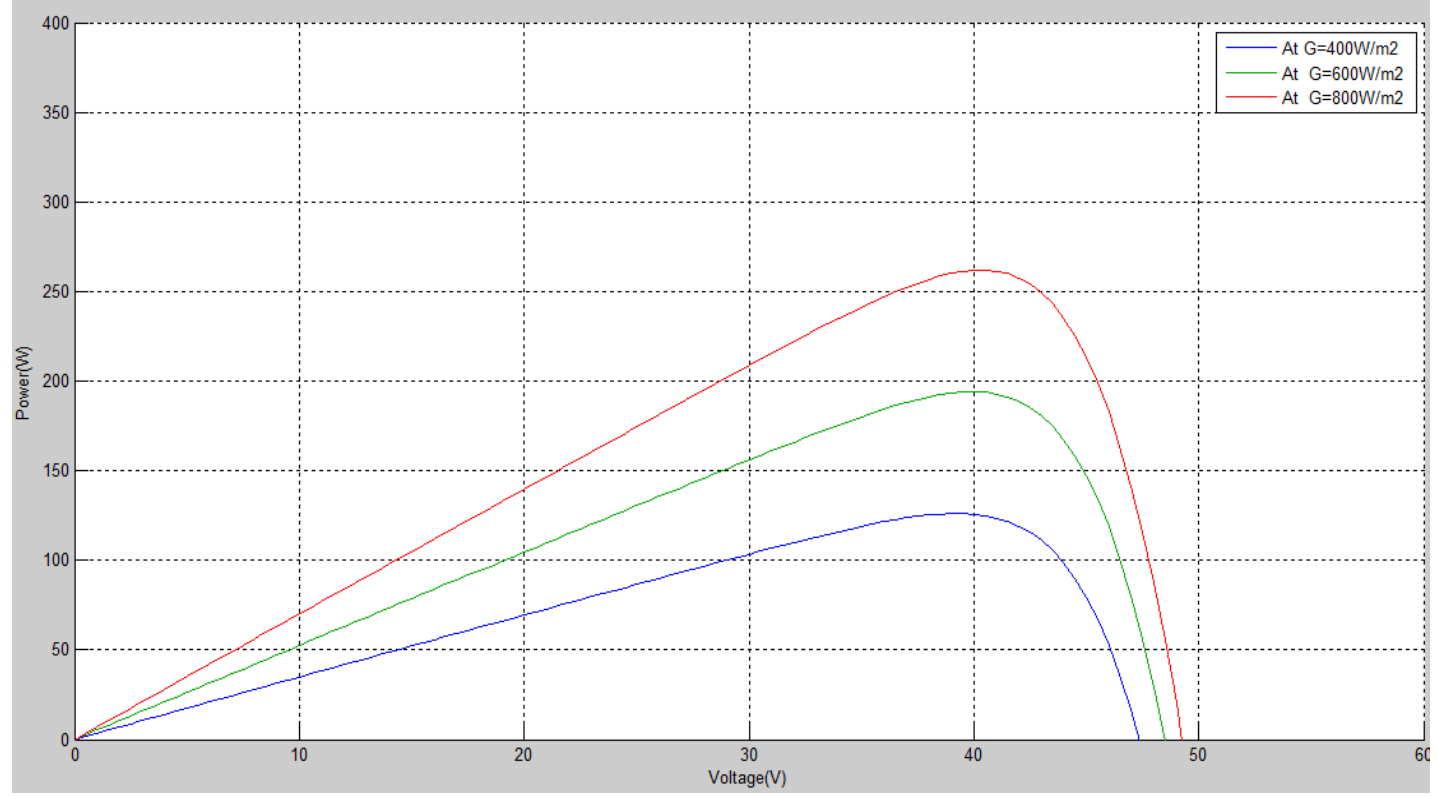

Table:5:-

\begin{tabular}{|c|c|c|c|}
\hline \multirow{2}{*}{$\begin{array}{l}\text { Parameters of } \\
\text { KD330GX-LFB } \\
\text { At } G=1000 \mathrm{~W} / \mathrm{m}^{2} \text { and } \\
\text { T }=25^{0} \mathrm{C}\end{array}$} & \multicolumn{3}{|c|}{$\begin{array}{l}\text { Simulink model Parameters } \\
\text { Under varying irradiance }\left(\mathrm{W} / \mathbf{m}^{2}\right)\end{array}$} \\
\hline & $G=400$ & $G=600$ & $\mathbf{G}=\mathbf{8 0 0}$ \\
\hline $\operatorname{Pmax}=330 \mathrm{~W}$ & 125.7 & 194 & 262 \\
\hline$V m p=40.5 \mathrm{~V}$ & 40 & 40 & 40.5 \\
\hline $\operatorname{Imp}=8.15 \mathrm{~A}$ & 3.14 & 4.85 & 6.47 \\
\hline Voc $=49.9 \mathrm{~V}$ & 47.3 & 48.5 & 49.3 \\
\hline$I s c=8.79 A$ & 3.51 & 5.27 & 7.02 \\
\hline
\end{tabular}

Table-6:- Change of Efficiency with Irradiance:

\begin{tabular}{|l|l|l|}
\hline $\begin{array}{l}\text { Irradiance } \\
\left(\mathbf{W} / \mathbf{m}^{2}\right)\end{array}$ & $\begin{array}{l}\text { Fill Factor } \\
(\%)\end{array}$ & $\begin{array}{l}\text { Efficiency } \\
(\%)\end{array}$ \\
\hline $\mathbf{G}=\mathbf{4 0 0}$ & $\mathbf{7 5 . 6 5}$ & $\mathbf{1 4 . 6 9}$ \\
\hline $\mathbf{G}=\mathbf{6 0 0}$ & $\mathbf{7 5 . 9 0}$ & $\mathbf{1 5 . 1}$ \\
\hline $\mathbf{G}=\mathbf{8 0 0}$ & $\mathbf{7 5 . 7 1}$ & $\mathbf{1 5 . 5}$ \\
\hline
\end{tabular}




\section{I-V Graph for KD325GX-LFB:}

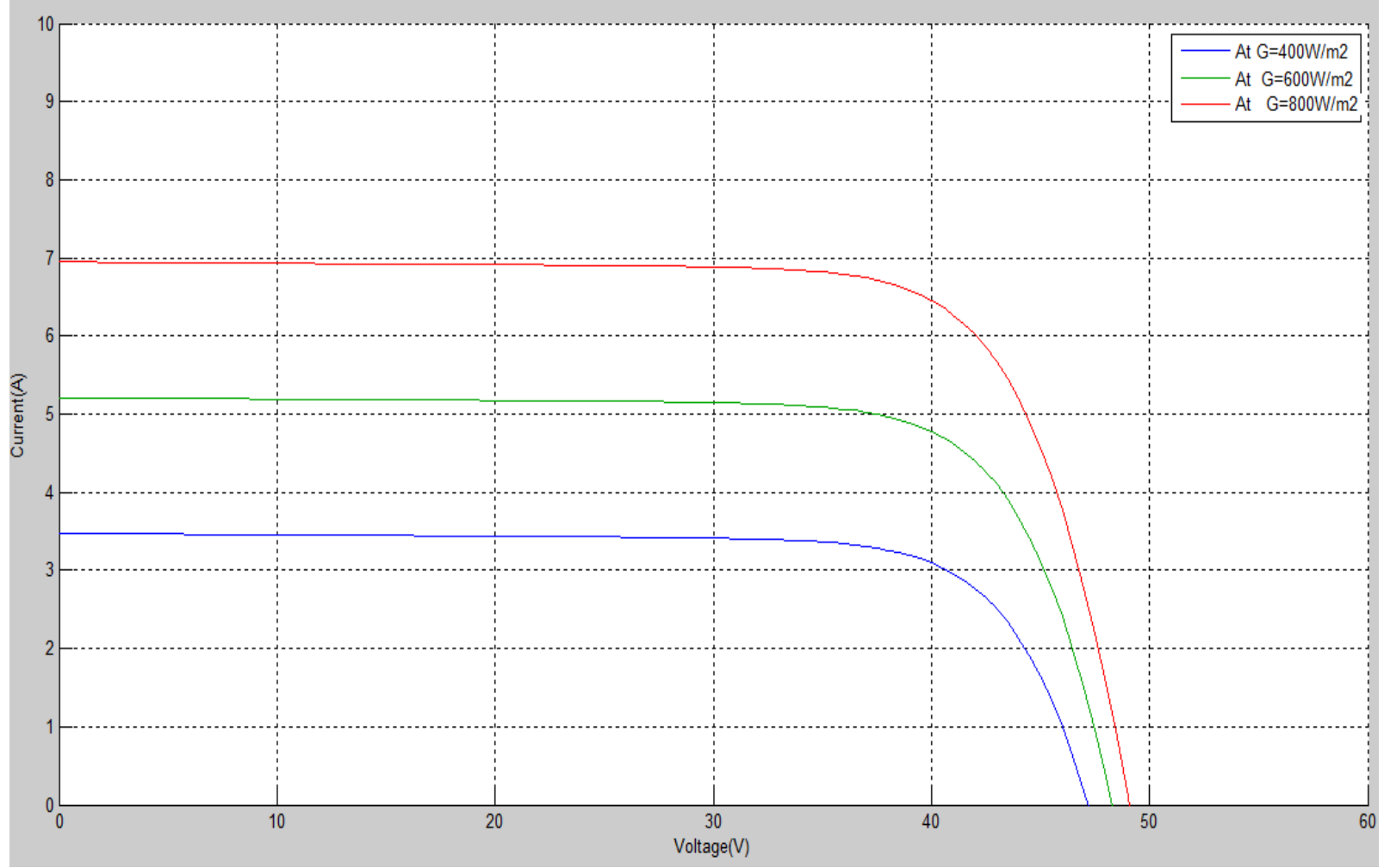

\section{P-V Graph for KD325GX-LFB:}

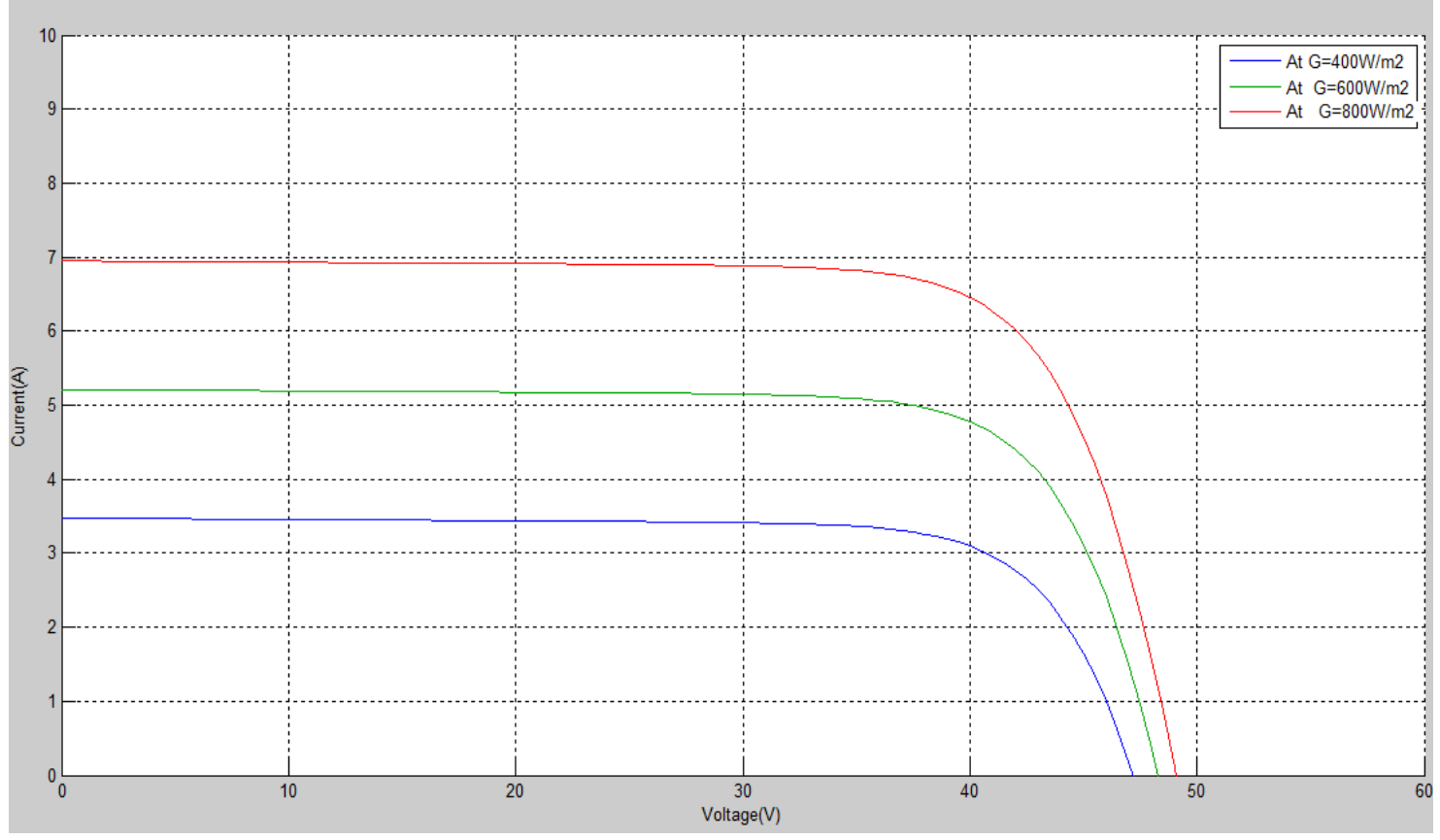


Table-7:

\begin{tabular}{|l|l|l|l|}
\hline \multirow{2}{*}{ Parameters of KD325GX-LFB } & \multicolumn{3}{|l|}{$\begin{array}{l}\text { Simulink model parameters } \\
\text { Under varying irradiance }\left(\mathrm{W} / \mathbf{m}^{2}\right)\end{array}$} \\
\cline { 2 - 4 } & G=400 & $\mathbf{G}=600$ & G=800 \\
\hline Pmax $=325 \mathrm{~W}$ & 123.8 & $\mathbf{1 9 1 . 2}$ & $\mathbf{2 5 8 . 1}$ \\
\hline Vmp=40.3V & 40 & $\mathbf{4 0}$ & $\mathbf{4 0 . 5}$ \\
\hline Imp=8.07A & 3.1 & 4.78 & 6.38 \\
\hline Voc=49.7V & 47.2 & 48.3 & 49.1 \\
\hline Isc=8.69A & 3.47 & $\mathbf{5 . 2 1}$ & $\mathbf{6 . 9 5}$ \\
\hline
\end{tabular}

\section{Change of Efficiency with Irradiance:}

\section{Table 8:-}

\begin{tabular}{|l|l|l|}
\hline Irradiance $\left(\mathbf{W} / \mathbf{m}^{2}\right)$ & Fill Factor $(\%)$ & Efficiency $(\%)$ \\
\hline $\mathbf{G}=\mathbf{4 0 0}$ & $\mathbf{7 5 . 6 5}$ & $\mathbf{1 4 . 8 8}$ \\
\hline $\mathbf{G}=\mathbf{6 0 0}$ & $\mathbf{7 5 . 9 0}$ & $\mathbf{1 5 . 3 2}$ \\
\hline $\mathbf{G}=\mathbf{8 0 0}$ & $\mathbf{7 5 . 7 1}$ & 15.54 \\
\hline
\end{tabular}

Constant Parameters used for Simulation:

Ideality factor $(\mathrm{a})=1.3$

Number of cells $(\mathrm{Ns})=80$

Boltzmann constant $(\mathrm{K})=1.38 * 10^{-23} \mathrm{~W} / \mathrm{m}^{2} . \mathrm{K}$

Energy gap(E.g.) $=1.12$.

Electron charge $(\mathrm{q})=1.602 * 10^{-19} \mathrm{C}$

\section{Conclusion:-}

From Table-1,Table-3 as the temperature increases maximum power, open circuit voltage decreases and short circuit current increases ultimately efficiency decreases .Table -2 and Table- 4 represents the change in efficiency and fill factor, from those We can conclude that as, the temperature increases the efficiency decreases ,This is because of increased intrinsic recombination. By the increase of heat energy, band gap of semi conductor decreases the open circuit voltage which is a function of band gap, decreases faster than the increase in the short circuit current so it leads to the decrease in the efficiency. The negative temperature coefficient of Silicon material reveals that as the temperature increases, the maximum power output decreases. The Table- 5 and Table- 7 represents the changes in the parameters of solar cell with the change in the irradiance. The Table- 6 and Table- 8 represents the changes in the efficiency and fill factor with the changes in the irradiance. As the irradiance increases, the number of photons incidenting on the module produces maximum power and leads to increase in the efficiency. This generalized simulink model is used to study the changes in the output parameters of any photovoltaic module by using Newton-Rapshon numerical method to identify the suitable resistances.

\section{References:-}

1. S. Leva, D. Zaninelli, Technical and Financial Analysis for Hybrid Photovoltaic Power Generation Systems, WSEAS Transactions on Power Systems, vol.5, no.1, May 2006, pp.831-838

2. S. Leva, D. Zaninelli, R. Contino, Integrated renewable sources for supplying remote power systems, WSEAS Transactions on Power Systems, vol.2, no.2, February 2007, pp.41-48.

3. Tsai, H.L, Tu, C.S and Su, Y.J. „Development of Generalized Photovoltaic Model Using MATLAB/Simulinke, Proceedings of the World Congress on Engineering and Computer Science (WCECS '08) San Francisco (USA), 2008.

4. Temperature Dependent Photovoltaic (PV) Efficiency and Its Effect on PV Production in the World A Review Swapnil Dubey*, Jatin Narotam Sarvaiya, Bharath Seshadri Energy Research Institute, Nanyang Technological University (ERI@N), \#06-04 CleanTech One, 1 CleanTech Loop, Singapore 637141, Singapore.

5. The Effect of Temperature on the Performance of A Photovoltaic Solar System In Eastern Nigeria Ike, C. U. Department of Physics/Industrial Physics Nnamdi Azikiwe University, Awka, Nigeria, Research Inventy: International Journal Of Engineering And Science Vol.3, Issue 12(December 2013), PP 10-14 Issn(e): 22784721, Issn(p):2319-6483. 
6. Matlab/Simulink Modeling to study the effect of partially shaded condition on Photovoltaic array's Maximum Power Point, Khaled Matter1, Hala J. El-Khozondar 2, Rifa J. El-Khozondar3, Teuvo Suntio4 , , International Research Journal of Engineering and Technology (IRJET) e-ISSN: 2395 -0056 Volume: 02 Issue: 02 | May2015

7. MATLAB/Simulink Based Modelling of Solar Photovoltaic Cell Tarak Salmi*, Mounir Bouzguenda**, Adel Gastli**, Ahmed Masmoudi* . INTERNATIONAL JOURNAL of RENEWABLE ENERGY RESEARCH Tarak Salmi et al., Vol.2, No.2, 2012.

8. Jay Patel1, Gaurag Sharma2 1 PG Student, 2Assistant professor Electrical department, Birla Vishvakarma Mahavidhyalaya, Gujarat, India. ISSN: 2319-1163. MODELING AND SIMULATION OF SOLAR PHOTOVOLTAIC MODULE USING MATLAB / SIMULINK IJRET: International Journal of Research in Engineering and Technology.

9. Modelling and Simulation of Solar PV Module on MATLAB/Simulink International Journal of Innovative Research in Science, Engineering and Technology ISSN(Online): 2319 - 8753 ISSN (Print) :2347 - 6710.

10. A detailed modeling of photovoltaic module using MATLABHabbati Bellia a, ${ }^{*}$, Ramdani Youcef Moulay Fatima ba Universite Bechar, Algeria Universite Sidi-Bel-Abbes, Algeria. NRIAG Journal of Astronomy and Geophysics.

11. M. Bashahua, P. Nkundabakura, "Review and tests of methods for the determination of the solar cell junction ideality factors," Solar Energy 81 856-863. 2007.

12. KD 300-80 F Series KD325GX-LFB KD330GX-LFB KYOCERA.

13. A.D. Rajapakse, D. Muthumuni," Simulation tools for photovoltaic system grid integration studies," Electrical Power Energy Conference (EPEC), IEEE, pp. 1-5, 2009.

14. M. Bashahua, P. Nkundabakura, "Review and tests of methods for the determination of the solar cell junction ideality factors," Solar Energy 81 856-863. 2007.

15. Ali Naci Celik, Nasir Acikgoz, "Modelling and experimental verification of the operating current of monocrystalline photovoltaic modules using four- and fiveparameter models, "Applied Energy 84 1-15, 2007. 